\title{
Effect of Foreign Exchange Risk Hedging Techniques on Financial Performance of Listed Firms in Kenya
}

\author{
Monica Wanjiru Muiru (Corresponding author) \\ Department of Accounting, Finance and Management Science \\ Egerton University, P.O. Box 26426-00100, Nairobi, Kenya \\ Email: muirumonica@gmail.com \\ Sifunjo E. Kisaka \\ Department of Finance and Accounting, School of Business \\ University of Nairobi, Nairobi, Kenya \\ Fredrick Kalui \\ Department of Accounting, Finance and Management Science \\ Egerton University, Nairobi, Kenya
}

Received: August 17, 2018 Accepted: September 9, 2018 Published: September 16, 2018

doi:10.5296/ijafr.v8i3.13512

URL: https://doi.org/10.5296/ijafr.v8i3.13512

\begin{abstract}
The adoption of floating foreign exchange rate regime in the 1990s and international trade have led to increased exposure of Kenyan firms to foreign exchange risk. Foreign exchange risk can affect a firm's expected cash flows, and by extension, its financial performance. This paper examines the effects of foreign exchange risk hedging techniques on the financial performance of publicly listed firms in Kenya. The target population constituted all the 54 firms that were continuously listed on the Nairobi Securities Exchange during the study period, from 2011 to 2016. The study used panel data research design. Secondary data was obtained from financial statements of the listed firms. The data was coded and analysed using descriptive and inferential statistics-correlation and regression-with the aid of STATA software. The feasible generalised least square model was used to test the hypotheses. The
\end{abstract}


results show currency hedging has a positive effect on financial performance. This implies that when hedging strategies and hedging tools are implemented appropriately, they help firms achieve their financial objectives, increasing financial performance, hence creating value for shareholders.

Keywords: Foreign exchange risk, Financial hedging, Natural hedging, Financial performance, Transaction exposure, Economic exposure, Translation exposure, Feasible generalised least square model

\section{Introduction}

Globalization of national economies, floating foreign exchange rate regimes and international trade have led to increased exposure of firms to foreign exchange risk. Foreign exchange risk is the sensitivity of a firm's cash flows to unanticipated changes in exchange rates (Ito, Koibuchi, Sato and Shimizu 2013). Foreign exchange risk, also commonly referred to as currency risk, is more pronounced in businesses that deal with more than one currency in their import and export transactions. This risk can negatively impact the financial performance of a firm. For example, a depreciating home currency can increases cost of imports, cost of servicing foreign debts, and cost of investing overseas. Similarly, an appreciating home currency can make exports more expensive and less competitive in the international markets. The appreciating home currency can decrease the value of investments in foreign subsidiaries and monetary assets, decrease the value of revenue from exports and incomes from abroad when converted into home currency. Thus, the effects of changes in the value of home currency can reduce profitability, and consequently lead to a decline of the firm's value.

There are three types of foreign exchange risk: transaction, economic and translation exposure. Transaction exposure arises when a firm has contractual cash flows that are fixed in a foreign currency (Shapiro 2013). If a firm has a receivable or a payable denominated in foreign currency, a change in the value of the foreign currency will increase or reduce the expected future cash flows. If the firm does not address this uncertainty, then the firm's value will be affected. Transaction exposure can be reduced by applying financial and operational hedging strategies. Economic exposure refers to the impact of exchange rate movements on the present value of expected future cash flows (Döhring, 2008). It is concerned with the effect of long-term movements in exchange rates on the firms' expected future cash flows and, in turn, their overall market values (Dhanani, 2003). Economic risk is sometimes considered to be an extension of transaction exchange risk in that it is related to cash flows that are yet to be received (Dhanani, 2003). Empirical studies carried out in the 1990s and earlier on economic exchange rate risk indicated that many firms often did little to manage economic risk. However, other studies showed that firms were actively managing economic exchange risk using operational hedging (Kim \& McElreath, 2001).

Translation exposure refers to the effect that an unanticipated change in exchange rates will have on the value of foreign subsidiaries' assets and liabilities dominated in foreign currency when these values are being translated into home currency on the consolidated financial statements of a firm (Shapiro 2013). The process of translation, coupled with movements in 
exchange rates, may give rise to translation gains or losses in the financial statements when firms try to balance the statements. These gains and losses are commonly termed as translation risk (Dhanani, 2003). Translation exposure can be controlled through a balance sheet hedge and derivatives hedge. The focus of this study was on transaction and economic risks because majority of Kenyan firms have few international subsidiaries, hence translation risk is rare.

Foreign exchange hedging techniques are measures undertaken by a firm to manage or deal with the exchange risk. There two ways of classifying foreign exchange risk hedging techniques, according to hedging literature and according to financial statements classifications (Döhring, 2008). The hedging literature classify the techniques into financial and operational. Financial hedging techniques involve the use of financial derivatives like forwards, futures, money market hedge, swaps, options and foreign currency debt (Shapiro 2013). The operational hedging techniques incudes measures like: diversification across countries; operational matching of revenues and expenditure; netting inter-firm cash flows; currency choice in invoicing; leads and lags. The financial statement classifications, on the other hand, classifies the techniques into: derivative hedge and natural hedge. Derivative hedges include Forwards, Futures, Options and Swaps. The natural hedge includes foreign currency debt hedge and operational hedge. This study adopted the classification according to financial statement classifications, since most Kenyan firms engage in natural hedging.

Forward contract is an agreement between two parties for the delivery of an underlying asset for a specified delivery price at a specified future date. The underlying asset can be foreign currency or a commodity. Forward contracts are privately negotiated agreements between two parties and do not necessarily have standardized contract size and maturity (Liu, 2007). Futures contracts, on the other hand, are similar to forward contracts except that futures contracts are standardized and are traded in organized exchange. Futures contracts were initially designed for commodity trading, but as trading continued to evolve, the initial definition of "commodity" broadened to include exchange currencies (Liu, 2007). Currently, currency futures contracts are the most commonly used financial derivatives by international investors.

Money market hedge involve simultaneously borrowing and lending activities denominated in two different currencies aimed at locking-in the value of the home currency against the value of a foreign currency cash flow (Shapiro, 2013). The simultaneous borrowing and lending activities enable a firm to create a home-made forward contract. The money market and the forward market are identical because interest rate parity holds (Liu, 2007). Currency swaps, on the other hand, are contracts where two parties agree to exchange specified cash-flows denominated in different currencies at specified intervals. Currency options are contracts that give the holder the right, but not the obligation, to buy or sell a specified amount of foreign currency at a specified price, for a specified period of time (Sundaram \& Das, 2010).

Natural hedging is a strategy of minimizing exchange risk through using different financial instruments whose performance tends to cancel each other. The commonly used natural 
hedging techniques include: diversification across countries, matching costs and revenues, choice of invoice currency and price adjustment; netting inter-firm foreign exchange cash-flows; price adjustments; leading and lagging. The firm can shift, share or diversify foreign exchange risk by selecting the currency of invoice. For instance, a firm may decide to invoice all transactions in the home currency to avoid transaction exposure altogether. In addition, if the currencies of both the importer and exporter are not suitable for settling international trade, neither party can be able to share or shift the exchange risk (Eun \& Resnick, 2006). Price adjustment technique involves changing price to obtain the favorable effect of exchange rate changes (Al-Shboul, 2008). When the home currency of a subsidiary depreciates, the subsidiary can increase prices of exports to cancel the effect of depreciation. This technique is difficult to implement because it requires some signaling and timing of exchange rate changes and a firm cannot arbitrary change prices without considering the actions of competitors (Shapiro, 2013).

Leading and lagging is another natural hedging technique used by firms to minimize transaction exposure. According to Abor (2005), lead strategy involves attempting to collect foreign currency receivables only when a foreign currency is expected to depreciate and paying foreign currency payables before they are due when a currency is expected to appreciate and vice-verse. To "lead" means to pay the payables or collect the receivables early, and to "lag" means to pay the payables or collect the receivables late. Firms normally lead soft currency receivables and lag hard currencies receivables to avoid loss from the depreciation of the soft currencies and to gain from the appreciation of hard currencies. Exposure netting involves gathering all foreign currency cash flows from subsidiaries and grouping them together, so that the inflows are used to offset the outflows of the same currency. The firm then hedges the residual exposure (Eun \& Resnick, 2006).

The choice of exchange risk hedging techniques can be influenced by a number of factors, namely; size, amount of research and development expenditure, exposure to exchange rates through foreign sales and foreign trade, liquidity of the firm, ownership structure among others (Allayanis \& Ofek, 2001). Large companies are expected to have significant exposure to foreign exchange risk and it is believed that companies aggressively manage the risk (Bodnar \& Wong, 2000). Solakoglu, (2005) found that larger firms that are dependent on export revenue have lower exposure to exchange rate risk.

Financial performance refers to the extent to which financial objectives of a firm are being met. Different methods, including stock market based and accounting based ones, are used to measure financial performance. The two measures represent different perspectives on how to evaluate a firm's financial performance. However, they have different theoretical implications and may be subject to particular biases (Hillman \& Keim, 2001). Return on total assets (ROA) is the widely used accounting measure. It indicates the management's ability to convert assets into net earnings. The higher the ROA, the better the performance. The stock market-based measures, on the other hand, indicate the long-term financial performance of a firm, with an emphasis on the firm's ability to generate future economic earnings. The widely used market-based measures include Tobin's Q and market return. These measures are less susceptible to different accounting procedure and accounting manipulations. Both 
accounting-based and market-based measures are widely accepted as valid indicators of firm's financial performance (Gentry \& Shen 2010). This study used Tobin's Q as proxy for financial performance, borrowing from previous studies like (Wolfe \& Sauaia 2003) and (Li, Visaltanachoti, \& Luo 2014).

\section{Research Objective}

The primary objective of this study was to determine the effect of foreign exchange risk hedging techniques on financial performance of listed firms in Kenya. To achieve this, the following specific objectives were formulated:

i. To determine the effect of financial hedging techniques on financial performance of listed firms in Kenya

ii. To evaluate the effect of natural hedging techniques on financial performance of listed firms in Kenya

iii. To determine the joint effect of financial hedging techniques and natural hedging on financial performance of listed firms in Kenya

\section{Hypotheses of the Study}

To investigate the topic under study, the following hypothesis stated in null form were tested:

$\mathrm{H}_{01}$ : There is no significant effect of financial hedging techniques on the financial performance of listed firms in Kenya.

$\mathrm{H}_{02}$ : There is no significant effect of natural hedging techniques on the financial performance of listed firms in Kenya.

$\mathrm{H}_{03}$ : There is no significant effect of joint financial hedging and natural hedging techniques on the financial performance of listed firms in Kenya.

\section{Empirical Review}

There exists a fairly impressive corpus of studies done in different countries on the foreign currency risk management through hedging techniques. Bartram, Brown and Fehle (2004) evaluated the use of financial derivative by firms across countries by examining 7319 non-financial firms from 50 countries. The study found that the use of general derivatives has a positive effect on the value of the firm. The study also found evidence that firms located in less liquid derivatives markets, characteristically in less developed countries, are less likely to hedge. Correspondingly, Allayannis and Weston (2001) examined the use foreign currency derivatives on a sample of 720 large U.S. non-financial firms. Using Tobin's Q for the estimate of the firm's value, the study found that the use of currency derivatives increases the value of the firm. Specifically, they found that firms that are exposed to foreign exchange risk and use currency derivatives have a 4.87 percent higher value than firm that do not use the currency derivatives.

Carter, Rogers and Simkins (2006) investigated jet fuel hedging behaviour of firms in the US airline industry during 1992-2003 to establish whether such hedging increases the value of 
these firms. Using Tobin's Q as proxy for firm value, they found that jet fuel hedging is positively related to airline firm's value. The study revealed that the greatest benefit of hedging in this industry was the reduction in underinvestment costs since the fuel price is highly correlated to the investment opportunities in the sector. On the contrary, Jin and Jorion (2006) investigated the effect of hedging on firm's value using 119 US oil and gas producers, and found no evidence that hedging has any significant positive effect on firm value of the firm in the oil and gas industry. However, the study concluded that hedging reduces the firm's stock prices sensitivity to oil and gas prices.

Nasurutia (2013) examined the effectiveness of derivatives in managing foreign exchange exposure among commercial banks in Kenya. The study focused on all the 10 listed commercial banks that were in operation during the period between 2008 and 2012. Using regression analysis, the study results indicated that derivative usage have a negative relationship with foreign exchange exposure, implying that an increase in derivative usage results in a corresponding decrease in foreign exchange exposure. This suggested that foreign exchange risk hedging minimized foreign exchange risk, thereby increasing the profitability of the commercial banks. Similarly, Mumoki (2009) assessed foreign exchange risk management strategies and techniques used by banks in Kenya to manage foreign exchange risk exposure. The study found that the forward contract was the most frequently used instrument, whereas futures contract, foreign currency option, leading and lagging techniques, and money market hedging are occasionally used by Kenyan commercial banks.

Ito, et al. (2013) investigated the relationship between Japanese firms' exposure to the exchange rate risk and risk management tools. Using a questionnaire survey covering all Tokyo Stock Exchange listed firms in 2009, the study adopted the Bodnar and Wang (2003) regression model, to estimate Japanese firms' exchange rate exposure. Using the Tokyo Stock Price Index (TOPIX) and MSCI Japan Index as proxy for market portfolios, the study found that firms that heavily depend on sales in foreign markets have greater foreign exchange risk and that most of these Japanese firms use a combination of multiple risk hedging tools to reduce foreign exchange rate risk. The study concluded that the commonly used techniques include; choice of invoicing currency, exchange rate pass-through, financial and operational hedges.

Nova, Antonio, and Brandão (2015) examined the impacts of risk hedging strategies with financial derivatives on firm's market value, using non-financial firms listed in the FTSE-350 share index at the London Stock Exchange. Using OLS estimation method, the study found a positive and statistically significant impact of foreign exchange rate derivatives on firm market value, implying that markets and investors appreciate hedging policies and hence reward firms pursuing such policies with higher firm value. Likewise, Ahmed, Azevedo, and Guney, (2014) found that the effect of hedging on firm value and financial performance varies across financial risks. The study found evidence that financial derivatives are more effective in hedging currency risks, hence contributing positively to value creation and financial performance. 
Parlak and İlhan (2016) investigated the effect of foreign exchange open positions of manufacturing and service sector companies on financial performance in Turkey. The study used a sample of 30 firms for the period between third quarter of 2012 to the second quarter of 2015. Using the ANOVA test, the study revealed that companies with short foreign exchange positions were able to increase their overall profitability to a level comparable with companies with long foreign exchange positions when the local currency was overvalued, but these firms were exposed to serious losses when the local currency was devalued. Further, using regression analysis, the study indicated that companies with short foreign exchange position in the present period had higher liquidity, asset efficiency and lower overall profitability than companies with long foreign exchange position in the previous period.

Altuntas, Liebenberg, Watson, and Yildiz (2017) explored the relation between hedging, cash flows, and firm value. Specifically, the study assessed the impact of derivatives hedging on firm value both directly and indirectly through its effect on cash flow volatility. The study found that both derivatives hedging and cash flow volatility are negatively related to firm value. Overall, the study found that derivatives usage alone decreases firm value and performance. However, when the study evaluated the impact of hedging through cash flow volatility, the firms' value of the hedgers was found to be less sensitive to cash flow volatility compared to the value of non-hedgers.

Natural hedging strategies are measures used to minimize foreign exchange risk without using engaging the services of financial institutions. These measures include geographical diversification of operation and sales, leading and lagging, matching costs and revenues, amongst others. Gleason, Kim and Mathur (2005) evaluated the relationship of the operational and financial hedging strategies of U.S. high technology firms. Using a sample of 216 firms and regression analysis, the study found that firms that use derivatives are large and spend more on research and development than non-derivative users. Further, the study found evidence that financial hedging and operational hedging are complementary and that financial hedging add value to the firm while operational hedging does not. Similarly, Treanor, Carter, Rogers and Simkins (2013) analysed the operational hedges that are commonly used by airlines to determine if operational and financial hedges are complements or substitutes. The study found that most airlines are likely to use financial derivatives and that the use of financial derivatives increases firm value. Unexpectedly, the study found that the use of operational hedges decreases the value of the firm.

Choi and Jiang (2009) examined the relationship between multi-nationalism of a firm and its effect on exchange risk exposure. The study focused on the exchange risk exposure of US firms during 1983-2006, comparing multinational and non-multinational firms. Using a two-stage least square (2SLS) analysis, the study revealed that the financial hedging is insignificant while the operational hedging is significant in reducing exchange risk exposure. Likewise, Dong, Kouvelis and Su (2014) investigated the impact of operational flexibility on firms' economic exposure to currency fluctuations in the presence of global competition. The study focused on two operational strategies: matching currency footprints ("natural hedge") and the capacity pooling strategy with allocation flexibility. Using a two-stage stochastic 


\section{Ml Macrothink}

International Journal of Accounting and Financial Reporting

ISSN 2162-3082

2018, Vol. 8, No. 3

model, the researchers concluded operational hedging techniques increase profits and reasonably reduce the downside foreign exchange risk.

The abovementioned studies provide contradicting evidence on the effect of exchange hedging on firm's financial performance. Majority of these studies suggest that financial hedging increases the value of the firm, while others found no relationship between financial hedging and firm's financial performance. Other studies found that natural hedging has no effect on financial performance while others found that operational hedging increases financial performance, hence the value of the firm. This study, by hypothesising that there is significant effect of foreign exchange risk hedging on the financial performance of listed firms in Kenya, aimed at bridging this knowledge gap.

\section{Research Methodology}

\subsection{Research Design}

This study used both cross-sectional and longitudinal research design, organized as panel data, which assisted in analyzing the changes in the relationship across firms and in the variables over time. This design was deemed appropriate since the purpose of the study was to assess the effect of currency hedging techniques on the financial performance over a period of six years. It helped in generating the evidence necessary for making causal inferences about relationships between foreign exchange risk hedging techniques and financial performance within the firm and across time.

\subsection{Population and Sampling}

The target population comprised of all the 54 firms that were continuously listed on NSE during the study period from 2011 to 2016. The selection of the period was guided by previous studies on foreign exchange risk management and firm performance like (Aabo \& Brodin 2014) and (Carter, et al 2006). Since the study used all listed firms, sampling was not necessary.

\subsection{Data Collection}

Secondary data was extracted from the listed firm's audited financial statements from 2011 to 2016. The statements were obtained from the Capital Markets Authority, which collects data as part of its regulatory function, the Nairobi Securities Exchange (NSE) data banks and from the websites of these firms. The data was be collected and captured with the aid of data capture sheet.

\subsection{Measurement of Variables}

Table 1. Operationalization of the study variable

\begin{tabular}{lllll}
\hline Variable & Indicators & Source & Measurement & $\begin{array}{c}\text { Scale } \\
\text { Type }\end{array}$ \\
\hline Foreign & Financial & Marsden & A value of 1 is assigned if & Nominal \\
\hline
\end{tabular}




\begin{tabular}{llll}
\hline exchange & risk & hedging & and Prevost the firm reports the use of Scale \\
hedging & techniques & $(2005)$ & financial derivatives for \\
techniques & & $\begin{array}{l}\text { Bartram et hedging purpose and } 0 \text { if } \\
\text { al (2011) }\end{array}$ & otherwise
\end{tabular}

Natural hedging Judge techniques (2006)
A value of 1 is assigned if Nominal the firm reports the use of Scale natural hedging techniques and 0 if otherwise

$\begin{array}{llll}\begin{array}{l}\text { Financial } \\ \text { Performance }\end{array} & \text { Firm's Value } & \begin{array}{l}\text { Allayannis } \\ \text { and Weston }\end{array} & \begin{array}{l}\text { Tobin's } Q=\text { Total Market Ratio } \\ \text { value plus debt divided by }\end{array} \\ (2001) & \text { total assets }\end{array}$

The study variables were measurement as presented in table 1 above. The financial hedging techniques was measured using categorical variables, where a value of 1 was assigned if the firm reports the use of financial derivatives for hedging purpose and 0 if otherwise. Likewise, the natural hedging techniques were measured using dummy variables, where a value of 1 was assigned if the firm reports the use of natural hedging techniques and 0 if otherwise. Financial performance was measured using Tobin's Q as the proxy for firm's value. Tobin's Q, which was developed by James Tobin, compares the value of a company given by financial markets with the value of a company's assets ( $\mathrm{Li}$, et al, 2014). Tobin's Q is calculated as the ratio of the market value of the firm to the replacement cost of its assets however due to limitations in the availability of data, this study used the modified version applied by most of the researchers in similar studies like (Wolfe \& Sauaia 2003) and (Li, et al, 2014). The modified ratio is calculated by dividing the market value of a company plus debt divided by the value of its total assets.

\section{Data Analysis}

Data was analyzed using descriptive and inferential statistics. The descriptive statistics used were mean, median and standard deviation. The inferential statistics used were correlation and regression analysis. The analysis was done with aid of the STATA software. The multiple regression model used was as follows:

$$
Y_{i t}=\beta_{0}+\beta_{1} X_{1 i t}+\beta_{2} X_{2 i t}+\varepsilon_{i t}
$$

Where:

$Y_{i t}=$ Financial Performance for firm i at time $\mathrm{t}$

$\beta_{0}=\mathrm{Y}$ intercept

$\beta_{1}$ and $\beta_{2}=$ regression coefficients

$\mathrm{X}_{1}=$ Financial hedging techniques for firm $\mathrm{i}$ at time $\mathrm{t}$ 
$\mathrm{X}_{2}=$ Natural hedging techniques for firm $\mathrm{i}$ at time $\mathrm{t}$

$\varepsilon=$ regression error term

\subsection{Descriptive Analysis}

The independent variable was foreign exchange risk hedging techniques whose influence on financial performance was sought in the study. Foreign exchange risk hedging techniques was measured using the indicators; financial hedging techniques and natural hedging techniques. Both were measured on a binary categorical scale.

Table 2. FX risk hedging techniques

\section{Proportion Std. Err. Binomial Wald}

[95\% Conf. Interval]

\begin{tabular}{lccccc}
\hline $\begin{array}{l}\text { Financial } \\
\text { Hedging }\end{array}$ & 0 & .7585139 & .0238506 & .7115912 & .8054367 \\
& 1 & .2414861 & .0238506 & .1945633 & .2884088 \\
& & .504644 & .0278627 & .449828 & .5594599 \\
$\begin{array}{l}\text { Natural } \\
\text { Hedging }\end{array}$ & 0 & .495356 & .0278627 & .4405401 & .550172 \\
& 1 & & & & \\
\end{tabular}

Table 2 above, presents a summary of hedging techniques; financial and natural hedging. Similar to Marsden and Prevost (2005); and Bartram et al (2011) the hedging techniques were measured using dummy variables where the value of 1 was assigned if the firm report the use of financial derivatives for hedging purpose and 0 if otherwise. Also the value of 1 was assigned to firms that use natural hedging and 0 if otherwise. Amongst all the listed firms, 49\% use natural hedging and 50\% do not use natural hedging. On the other hand, $24 \%$ use financial hedging and $75 \%$ do not use financial hedging. These findings are consistent with Afza and Alam (2016) study, which revealed that the fewer firm in developing countries use financial derivatives compared to their counterparts in developed countries.

Table 3. One-way tabulation panel statistics for financial hedging

\begin{tabular}{llllll}
\hline & Overall & & Between & & Within \\
Financial Hedging & Freq. & Percent & Freq. & Percent & Percent \\
\hline 0 & 246 & 75.93 & 41 & 75.93 & 100 \\
1 & 78 & 24.07 & 13 & 24.07 & 100 \\
Total & 324 & 100 & 54 & 100 & 100 \\
\hline
\end{tabular}




\section{Mll Macrothink}

International Journal of Accounting and Financial Reporting ISSN 2162-3082

Table 3 (above) shows the one-way tabulations and decomposed counts into between and within components of the panel data. The overall $75.93 \%$ of all the entity-years showed no financial hedging, while only $24.07 \%$ showed financial hedging practice. The between proportions show that $75.93 \%$ of all the entities practiced financial hedging. This proportion is equal to the overall proportion, implying that the entire overall proportion was due to the variability within the entities. This is also shown by the $100 \%$ percentages within which it is shown that financial hedging was a time-invariant variable.

Table 4. One-way tabulation panel statistics for natural hedging

\begin{tabular}{llllll}
\hline & Overall & & Between & & Within \\
Natural Hedging & Freq. & Percent & Freq. & Percent & Percent \\
\hline 0 & 168 & 51.85 & 28 & 51.85 & 100 \\
1 & 156 & 48.15 & 26 & 48.15 & 100 \\
Total & 324 & 100 & 54 & 100 & 100 \\
\hline
\end{tabular}

Table 4 (above) also shows the tabulation for natural hedging. This variable was also shown to be time-invariant within the percentages of $100 \%$. The overall proportions of those firms that do not use natural hedging was $51.85 \%$ while $48.15 \%$ of the entities practiced natural hedging all through the years.

\section{Results}

\subsection{Model Specification and Regression Diagnostic Tests}

The objective of the study was to determine the effect of foreign exchange risk hedging techniques on financial performance of listed firms in Kenya. Foreign exchange hedging techniques were regressed on financial performance to test the hypotheses and draw conclusions on the objectives. The Feasible Generalized Least Squares (FGLS) model was adopted after Hausman test was done for model specification and which favoured the use of the random effect model. Thereafter diagnostic tests on the random effect model were done and all the regression assumptions were violated. The test results are presented in the table below.

Table 5. Model specification and assumption tests

\begin{tabular}{lllll}
\hline Test & $\begin{array}{l}\text { Assumption/ } \\
\text { Purpose }\end{array}$ & Test statistic & $\begin{array}{l}\text { P-valu } \\
\text { e }\end{array}$ & Conclusion \\
\hline Hausman & $\begin{array}{l}\text { Model } \\
\text { specification }\end{array}$ & Chi2(2) $=1.18$ & 0.5548 & $\begin{array}{l}\text { Adopt } \\
\text { random }\end{array}$ \\
\hline
\end{tabular}


(fixed/ random)

effect

\begin{tabular}{|c|c|c|c|c|}
\hline $\begin{array}{l}\text { Breusch-Godfrey/Wooldrid } \\
\text { ge }\end{array}$ & $\begin{array}{l}\text { Non-Serial } \\
\text { correlation }\end{array}$ & $\mathrm{F}(1,53)$ & 0.0089 & $\begin{array}{l}\text { Assumption } \\
\text { violated }\end{array}$ \\
\hline Wald & Homoscedasticity & $\begin{array}{l}\text { Chi2(53) } \\
296000000\end{array}$ & $=0.000$ & $\begin{array}{l}\text { Assumption } \\
\text { violated }\end{array}$ \\
\hline Bera-Jarque (JB) & Normality on e & $\operatorname{chi} 2(2)=8.05$ & 0.017 & $\begin{array}{l}\text { Assumption } \\
\text { violated }\end{array}$ \\
\hline Bera-Jarque (JB) & Normality on $\mathrm{u}$ & $\begin{array}{l}\operatorname{chi} 2(2) \\
3883.84\end{array}$ & $=0.045$ & $\begin{array}{l}\text { Assumption } \\
\text { violated }\end{array}$ \\
\hline Pesaran Friedman test & $\begin{array}{l}\text { Cross-sectional } \\
\text { dependence }\end{array}$ & $\begin{array}{l}\text { Pesaran's } \\
=19.157\end{array}$ & Z $\quad 0.000$ & $\begin{array}{l}\text { Assumption } \\
\text { violated }\end{array}$ \\
\hline
\end{tabular}

Table 5 above summarizes the model specification and regression diagnostic tests. Hausman test was used to choose between the fixed and random effect model. The test's null hypothesis stated: random effect model is appropriate, while the alternate stated: fixed effect model is appropriate. The Wald chi-square statistic computed was 1.18 with a p-value of 0.5548 . The p-value of the Chi-square statistic was greater than 0.05 , thus the null hypothesis was rejected and alternate hypothesis accepted. This means that the random effect model was the preferred model for testing the effect of hedging on financial performance. The Wooldridge F-statistic was used to test the existence of serial correlation and the p value of the F-statistics was 0.0089 which was less the 0.05 , indicating the presence of serial correlation. Panel data model estimation also assumes panel homoscedasticity of the error variances (Hsiao, 2003). To test for the existence of significant heteroscedastic error variances, which disqualifies the homoscedasticity assumption, Wald test was used. The p-value of the Wald statistic was 0.000 , which is less than 0.05 implying presence of heteroscedasticity.

Alejo, Galvao, and Montes-Rojas (2015) recommends checking for non-normal errors in regression models. The Bera-Jarque (JB) test for the normality of the error was used. The JB chi-square statistics for the $\mathrm{e}$ and $\mathrm{u}$ components had p-values of 0.017 and 0.0454 respectively. Both were less than 0.05 , implying that the error components were not normally distributed thus a violation of the normality assumption. Another assumption when estimating panel data models is that of cross-sectional independence which assumes that cross-sectional observations are not correlated. The Pesaran Friedman test for cross-sectional dependence in random effect models was carried and the $\mathrm{p}$-value of the $\mathrm{Z}$ statistic was 0.000 , which is less than 0.05 implying presence of cross-sectional correlation of the residuals. The assumption of cross sectional independence was thus violated. 


\subsection{Test of Hypotheses}

The following hypothesis were tested using the feasible generalized least squares method.

$\mathrm{H}_{01}$ : There is no significant effect of financial hedging techniques on the financial performance of listed firms in Kenya

$\mathrm{H}_{02}$ : There is no significant effect of natural hedging techniques on the financial performance of listed firms in Kenya

The financial hedging and the natural hedging techniques were regressed on financial performance, the results are as shown in table 6 below.

Table 6. Feasible generalized least squares financial and natural risk hedging

\section{Panels: Heteroskedastic with cross-sectional correlation}

Correlation: common AR(1) coefficient for all panels (0.8788)

$\begin{array}{llll}\text { Estimated covariances } & =1485 & \text { Number of Obs } & =324 \\ \text { Estimated autocorrelations } & =1 & \text { Number of groups } & =54 \\ \text { Estimated coefficients } & =2 & \text { Time periods: } & =6 \\ & \text { Wald chi2 }(3) & =6.19 \\ & \text { Prob }>\text { chi } 2 & =0.045\end{array}$

Coefficients. Bootstrap Std. Err. Z $\quad$ P $>/ \mathbf{z} /$

$\begin{array}{lllll}\text { Financial hedging } & 0.824 & 1.641 & 0.500 & 0.616 \\ \text { Natural hedging } & 3.430 & 1.391 & 2.470 & 0.014\end{array}$

Table 6 (above) shows that the FGLS model is generally significant with a Wald chi-square statistic $\left(\chi^{2}=6.19, \mathrm{p}\right.$-value $\left.=0.045\right)$. The model also shows that natural hedging has a significant influence on financial performance $(\beta=3.430 \mathrm{Z}=2.47, \mathrm{p}$-value $=0.014)$. The significance is implied by the $z$-statistic that has a $p$-value that is less than 0.05 . Financial hedging on the other hand was found to have a coefficient $(\beta=0.824 \mathrm{Z}=0.500$, $\mathrm{p}$-value $=$ 0.616). The $\mathrm{p}$-value of the statistic is greater than 0.05 implying insignificance of the coefficient.

$\mathrm{H}_{03}$ : There is no significant joint effect of financial hedging and natural hedging techniques on the financial performance of listed firms in Kenya 


\section{Mll Macrothink}

International Journal of Accounting and Financial Reporting

ISSN 2162-3082

2018, Vol. 8, No. 3

To assess the joint effect of the two types of hedging techniques on financial performance, another regression model was fitted, where the variable currency risk hedging considered hedging as a single binary variable, which took 1 for any entity that practiced any kind of hedging and 0 for an entity that did not practice hedging. The model adopted the FGLS approach. Table 7 below presents the results of the second model. The model allowed for heteroscedastic errors, cross-sectional correlations, had an autocorrelation bias correction of order 1 with a coefficient 0.898 and also adopted bootstrapping due to normality assumption violation

Table 7. FGLS regression analysis results

\section{Coefficients: generalized least squares}

Panels: heteroskedastic with cross-sectional correlation

Correlation: common AR(1) coefficient for all panels (0.898)

\begin{tabular}{|c|c|c|c|c|}
\hline Estimated covariances & $=1485$ & Number of Obs & $=$ & 324 \\
\hline Estimated autocorrelations & $=1$ & Number of groups & $=$ & 54 \\
\hline \multirow[t]{3}{*}{ Estimated coefficients } & $=1$ & Time periods: & $=$ & 6 \\
\hline & & Wald chi2(1) & $=$ & 4.670 \\
\hline & & Prob > chi 2 & $=$ & 0.030 \\
\hline
\end{tabular}

Coefficients. Bootstrap Std. Err. Z $\quad$ P $>/ \mathbf{z} /$

$\begin{array}{lllll}\text { Forex Risk Hedging } & 2.741 & 1.269 & 2.160 & 0.031\end{array}$

In table 7 above, the model Wald statistic $\left(\chi^{2}=4.670, p\right.$-value $\left.=0.031\right)$ shows a $p$-value less than 0.05 implying a significant model. The model further shows that forex hedging influences financial performance $(\beta=2.741 \mathrm{Z}=2.160$, $\mathrm{p}$-value $=0.031)$. The $\mathrm{p}$-value is less than 0.05 implying significance of the coefficient estimate. The estimated model formulated in an equation takes the form;

$$
Y_{i t}=2.741 X_{i t}+\mu_{i t}+\varepsilon_{i t}
$$

The p-value of the coefficient of forex hedging was found to be 0.03 which is less than 0.05 . The null hypothesis was rejected and a conclusion drawn that foreign exchange risk hedging has a significant effect on financial performance of listed firms in Kenya. Foreign exchange risk hedging is a binary time invariant variable taking on only 2 values 0 and 1 . The significant coefficient 2.741 implies that an entity practicing any form of foreign exchange risk hedging techniques whether financial or natural hedging is expected to have a Tobin's Q 
of 2.741 more than those that do not practice any form of hedging. Firms with Tobin's Q greater than one have better investment opportunities, higher growth potential and an indication that management have utilized the assets under their command in an efficient way, hence improve financial performance (Wolfe \& Sauaia 2003).

The findings are consistent with the theoretical proposition that hedging improve the financial performance of a firm. The findings also corroborates with previous studies which found that general hedging enhances the financial position and hence the value of the firm. Bartram et al. (2004) found evidence that the use of general derivatives has a positive effect on the value of the firm. The results are also consistent with findings that natural (operational) hedging techniques increase profits and reasonably reduce the downside foreign exchange risk (Dong, et al, 2014).

\section{Discussion and Recommendation}

The study has implications on risk management policy and practices. First, the study confirmed a positive effect of foreign exchange hedging techniques on financial performance. The study found out that majority of publicly listed Kenyan firms use natural hedging. Financial derivatives are not widely used, perhaps because the derivative market in Kenya is not well developed. Since the early 2000s, the Nairobi Securities Exchange (NSE) and the market regulator Capital Markets Authority (CMA) endeavoured to introduce and develop the Futures and Options Market Segment (FOMS). However, the progress has been very slow. These institutions should expedite the development of the derivatives markets, so that the hedging instruments are easily available to firms operating in Kenya.

\section{Conclusion}

Theoretically, there exists a nexus between hedging and financial performance of listed firms. This study has confirmed in Kenya what other studies have confirmed in other contexts, namely, that currency-hedging techniques are positively related to financial performance. This study confirmed that currency-hedging techniques have a positive effect on financial performance of publicly listed firms in Kenya. This implies that when hedging strategies and hedging tools are implemented appropriately, firms can achieve their financial objectives thereby increasing financial performance and creating value for shareholders.

The findings of the study have implications on risk management policy and practices of companies. Given the importance of hedging techniques that has been established in this study, it is vital that companies start to explore the whole repertoire of risk amelioration techniques, particularly those available in roster of innovative techniques of hedging. In order to take advantage of such techniques, however, the regulator and securities exchange must lead from the front by introducing cutting-edge financial instruments. In Kenya, the dearth of such instruments inhibits innovativeness surrounding risk management. For instance, the study found out that majority of listed Kenyan firms use natural hedging. Financial derivatives are not widely since the derivative market is not well developed. Since the early 2000s, the Nairobi Securities Exchange (NSE) and the market regulator Capital Markets Authority (CMA) endeavoured to introduce and develop the Futures and Options Market 
Segment (FOMS). However, the progress has been very slow. The study recommends adoption of appropriate policies and increased government support that will hasten the development of derivative markets in Kenya. Derivative markets will facilitate the availability of hedging instruments, helping firms eliminate the negative effects of volatility of the Kenya shilling, therefore improving financial performance.

\section{References}

Abor, J. (2005). Managing foreign exchange risk among Ghanaian firms. Journal of Risk Finance, 6(4), 306-318.

Afza, T., \& Alam, A. (2016). Foreign Currency Derivatives and Firm Value. European Online Journal of Natural and Social Sciences, 5(1), 1-14.

Ahmed, H., Azevedo, A., \& Guney, Y. (2014). The Effect of Hedging on Firm Value and Performance: Evidence from the Nonfinancial UK Firms. Working Paper, Hull University Business School.

Alejo, J., Galvao, A., Montes-Rojas, G., \& Sosa-Escudero, W. (2015). Tests for Normality in Linear Panel Data Models. Documento de Trabajo, 178, 1-11.

Allayanis, G., \& Ofek. E. (2001). Exchange rate exposure, hedging, and the use of foreign currency derivatives. Journal of International Money and Finance, 20, 273-296.

Allayannis, G., \& Weston, J. P. (2001). The use of foreign currency derivatives and firm market value. Review of Financial Studies, 14, 243-276.

Al-Shboul, M. (2008). An investigation into the effects of the use of financial and operational hedges on Australian corporate foreign currency risk exposure. PhD thesis, James Cook University.

Altuntas, M., Liebenberg, A. P., Watson, E. D., \& Yildiz, S. (2017). Hedging, cash flows, and firm value. Journal of Insurance Issues, 40(1), 1-22.

Bartram, S. M., Brown, G. W., \& Fehle, F. R. (2004). International evidence on financial derivative usage. Working Paper, Lancaster University.

Bartram, S., Brown, G., \& Conrad, J. (2011). The Effects of Derivatives on Firm Risk and Value. Journal of Financial and Quantitative Analysis, 46, 967-999.

Bodnar, G., \& Wong, F. (2000). Estimating exchange rate exposures: Some "weighty" issues. NBER Working Paper No. 7497.

Bodnar, G., \& Wong, F. (2003). Estimating exchange rate exposures: issues in model structure. Financial Management, 32(1), 35-67.

Carter, D. A., Rogers, D. A., \& Simkins, B. J. (2006). Hedging and Value in the U.S. Airline Industry. Journal of Applied Corporate Finance, 18(4), 21-33.

Choi, J. J., \& Jiang, C. (2009). Does multinationalism matter? Implications of operational hedging for the exchange risk exposure. Journal of Banking \& Finance, 33, 1973-1982. 


\section{Macrothink}

International Journal of Accounting and Financial Reporting

ISSN 2162-3082 2018, Vol. 8, No. 3

Dhanani, A. (2003). Foreign exchange risk management: a case in the mining industry. The British Accounting Review, 35-63.

Döhring, B. (2008). Hedging and invoicing strategies to reduce exchange rate exposure: a Euro-area perspective. European Commission Directorate-General Economic and Financial Affairs. Economic Paper No. 299.

Dong, L., Kouvelis, P., \& Su, P. (2014). Operational hedging strategies and competitive exposure to exchange rates. International Journal of Production Economics, 153, 215-229.

Eun, C. S., \& Resnick, B. G. (2007). International Financial Management (4th ed.). Boston, US: McGraw-Hill/Irwin.

Gentry, R. J., \& Shen, W. (2010). The relationship between accounting and market measures of firm financial performance: how strong is it?. Journal of Managerial Issues, XXII(4), 514-530.

Gleason, K. C., Kim, Y. S., \& Mathur. I. (2005). The Operational and Financial Hedging Strategies of U.S. High Technology Firms. Working Paper, Southern Illinois University.

Hillman, A. J., \& Keim, G. D. (2001). Shareholder value, stakeholder management, and social issues: What's the bottom line?. Strategic Management Journal, 22(2), 125-139.

Hsiao, C. (2003). Analysis of Panel data. Cambridge University Press. UK.

Ito, T., Koibuchi, S., Sato, K., \& Shimizu, J. (2013). Exchange rate exposure and exchange rate risk management: The case of Japanese exporting firms. The Research Institute of Economy, Trade and Industry (RIETI) Discussion Paper Series. Japan.

Jin, J., \& Jorion, P. (2006). Firm value and hedging: evidence from US oil and gas producers. Journal of Finance, 61(2), 893-919.

Judge, A. (2006). Why and how UK firms hedge. European Financial Management, 12(3), 407-441.

Kim, Y., \& McElreath, R. (2001). Managing operating exposure: a case study of the automobile industry. Multinational Business Review, 21-26.

Li, H., Visaltanachoti, N., \& Luo, R. H. (2014). Foreign Currency Derivatives and Firm Value: Evidence from New Zealand. Journal of Financial Risk Management, 3, 96-112.

Liu, C. H. (2007). Foreign exchange hedging and profit making strategy using leveraged spot contracts. PhD thesis, Victoria University.

Marsden, A., \& Prevost, A. (2005). Derivatives use, corporate governance, and legislative change: an empirical analysis of New Zealand listed companies. Journal of Business Finance and Accounting, 32(1), 255-295.

Mumoki, A. N. (2009). Foreign exchange risk management: strategies and techniques used by banks in Kenya to manage foreign exchange risk exposure. MBA Dissertation, University of Nairobi. 


\section{1l Macrothink}

International Journal of Accounting and Financial Reporting

ISSN 2162-3082 2018, Vol. 8, No. 3

Nasurutia, A. (2013). The effectiveness of financial derivatives in managing foreign exchange exposure among Commercial banks listed at the Nairobi Securities Exchange. $M B A$ Dissertation, University of Nairobi.

Nova, M., Antonio, C., \& Brandão, E. (2015). Hedging with Derivatives and Firm Value: Evidence for the non-financial firms listed on the London Stock Exchange. FEP-UP Working Paper, School of Economics and Management, University of Porto.

Parlak, D., \& İlhan, H. (2016). Foreign Exchange Risk and Financial Performance: The Case of Turkey. International Review of Economics and Management, 4(2), 1-15.

Shapiro, A. C. (2013). Multinational Financial Management (10th ed.). Hoboken, New Jersey: Wiley.

Sundaram, R. K., \& Das, S. R. (2010). Derivatives: principles and practice. Singapore: McGraw-Hill Higher Education.

Treanor, S. D., Carter, D. A., Rogers, D. A., \& Simkins, B. J. (2013). Operational and Financial Hedging: Friend or Foe? Evidence from the U.S. Airline Industry. Journal of Accounting and Finance, 13(6), 64-91.

Wolfe, J., \& Sauaia, A. C. (2003). The Tobin Q as a Company Performance Indicator. Developments in Business Simulation and Experiential Learning, 30, 155-159.

\section{Copyright Disclaimer}

Copyright for this article is retained by the author(s), with first publication rights granted to the journal.

This is an open-access article distributed under the terms and conditions of the Creative Commons Attribution license (http://creativecommons.org/licenses/by/4.0/) 